\title{
An Investigation into Solid Waste Problem in the Egyptian Construction Industry: A mini-review
}

\author{
Ahmed Osama Daoud ${ }^{1,2}$, Ayman Ahmed Ezzat Othman', Herbert Robinson², and Ali \\ Bayyati $^{2}$ \\ ${ }^{1}$ Faculty of Engineering, the British University in Egypt (BUE), Cairo, Egypt. \\ ${ }^{2}$ School of Built Environment and Architecture, London South Bank University (LSBU), London, England. \\ Corresponding author: \\ Ahmed Osama Daoud, Faculty of Engineering, the British University in Egypt (BUE), Rm. 104, Bldg. A, \\ Cairo-Suez Desert Road, Al-Shorouk, 11837, Cairo, Egypt. \\ Email: ahmed.daoud@bue.edu.eg
}

\begin{abstract}
Solid waste management (SWM) is one of the most critical global challenges nowadays. It has a severe negative effect on the triple bottom line of sustainability. Construction and demolition waste (CDW) contributes about $50 \%$ of the total global annual generated SW. In the particular case of the Middle East and North Africa (MENA) region including Egypt, the SW problem has become a major challenge, and the need to find sustainable solutions is overwhelming. However, the region faces several challenges that hinder the development of an effective and efficient SWM system. This has resulted in the predominance of
\end{abstract}


unsustainable SWM practices such as indiscriminate disposals. The aim of this paper is to investigate the escalating problem of SW in the MENA Region, while focusing on CDW in Egypt as a part of the total generated SW, by reviewing the most recent research papers, and technical and governmental reports on the SW problem. The main challenges towards effective and efficient SWM systems and recommendations for improvement are gathered in this study based on the explored literature. Findings from this study are expected to be beneficial to local and central governments, academics, construction industry practitioners, and policymakers contending with the problems of SW in the MENA region and especially CDW in Egypt.

\section{Keywords}

Solid waste, construction industry, construction and demolition waste, waste management, waste minimisation, MENA region, Egypt, sustainability.

\section{Introduction}

The construction industry is one of the most significant industries which contribute to the social and economic development of countries. It provides the community with high living standards through socio-economic projects and infrastructure facilities such as roads, hospitals, and schools. Unfortunately, construction and demolition waste (CDW) is a 
growing challenge which the whole globe faces (Hussin et al., 2013). CDW has been defined by the construction literature in various ways and there is no absolute definition for it. For instance, Tchobanoglous et al. (1977) defined CDW as "wastes from razed buildings and other structures are classified as demolition wastes. Wastes from the construction, remodelling, and repairing of individual residences, commercial buildings, and other structures are classified as construction wastes" (cited in Elgizawy et al., 2016, p.2). Also, Koskela (1992) defined CDW as any inefficiency that leads to the use of materials in larger quantities than those needed for the production of a building.

Alternatively, the US Environmental Protection Agency (EPA) (1995) defines CDW as "waste that is generated from the construction, renovation, repair, and demolition of structures such as residential and commercial buildings, roads, and bridges". On the other hand, Roche and Hegarty (2006) defined CDW as "surplus and damaged products and materials arising in the course of construction work or used temporarily during the process of onsite activities". Lu and Yuan (2011) claimed that the term CDW has been mentioned in the literature as an integral term representing materials waste generated due to construction activities without being restricted to a specific stage of construction or demolition. It is quite obvious that each study has its own perspective towards the definition of CDW based on the addressed research question and objectives (Lu and Yuan, 2011). 
According to the latest report published by the World Bank in 2012, it is expected that the amount of the solid waste (SW) generated worldwide will increase from 1.3 billion tonnes to 2.2 billion tonnes by 2025 (Hoornweg \& Bhada-Tata, 2012). CDW constitutes about half of the annual generated SW worldwide (Redling, 2018; Yılmaz and Bakış, 2015). A report published by Transparency Market Research in 2017 claims that there will be a tremendous increase in the volume of the CDW generated over the coming years (Redling, 2018). Unfortunately, dumping of CDW is a common global trend which negatively affects society and environment (Slowey, 2018).

In 2015, a pile of CDW led to a landslide in Shenzhen, China that killed more than 70 individuals and led to displacement of 900 individuals. This slide also led to destruction of many buildings including houses and factories. Some analysts blamed the Chinese Government for their reluctance to enforce laws and regulations regarding CDW disposal. In Minnesota, USA, CDW is negatively affecting the ground water. Due to the fact that disposed CDW is not regulated by SW regulations in Minnesota, the Minnesota Pollution Control Agency (MPCA) is working hard to introduce tougher standards to landfills that lack barriers between deposited materials and ground water (Slowey, 2018).

The main barriers that exist towards the proper management of CDW are absence of standardisation and efficient practices, lack of effective policies and education, deficiencies 
in awareness, low profit margins, and lack of technical and financial resources (Redling, 2018; Slowey, 2018). In the Middle East and North Africa (MENA) region, including Egypt, CDW dumping is the dominant practice which has led to the escalation of the SW problem resulting in serious negative impacts on society, environment, and economy, which are the triple bottom line (TBL) of sustainability (El-Sherbiny et al., 2011; Zafar, 2016; Nassour et al., 2016; Aden, 2017; United Nations Environment Programme (UNEP), 2009; Abdelhamid, 2014). Accordingly, proper actions and strict measures need to be taken to alleviate CDW problem in the MENA region.

\section{Research Methodology}

This paper investigates the recent challenges of SW problem in the MENA region and specifically in the Egyptian construction industry. This is achieved by surveying different

literature about the SW problem on the regional (i.e., MENA region) and local (i.e., Egyptian context) levels as shown in Figure 1. The surveyed literature includes research papers, and technical and governmental reports. The paper starts with discussing the current status of the SW problem in the MENA region and the main causes behind it. Then, it investigates the current status of the SW problem in the Egyptian context and the reasons behind it. After that, it focuses on the current status of CDW in the Egyptian construction industry and the main causes behind it . Moreover, it sheds the light on the emerging issues and the current 
recommendations to solve the SW problem in the MENA region and minimise CDW in the Egyptian construction industry. Finally, conclusion and recommendations for future research are stated.

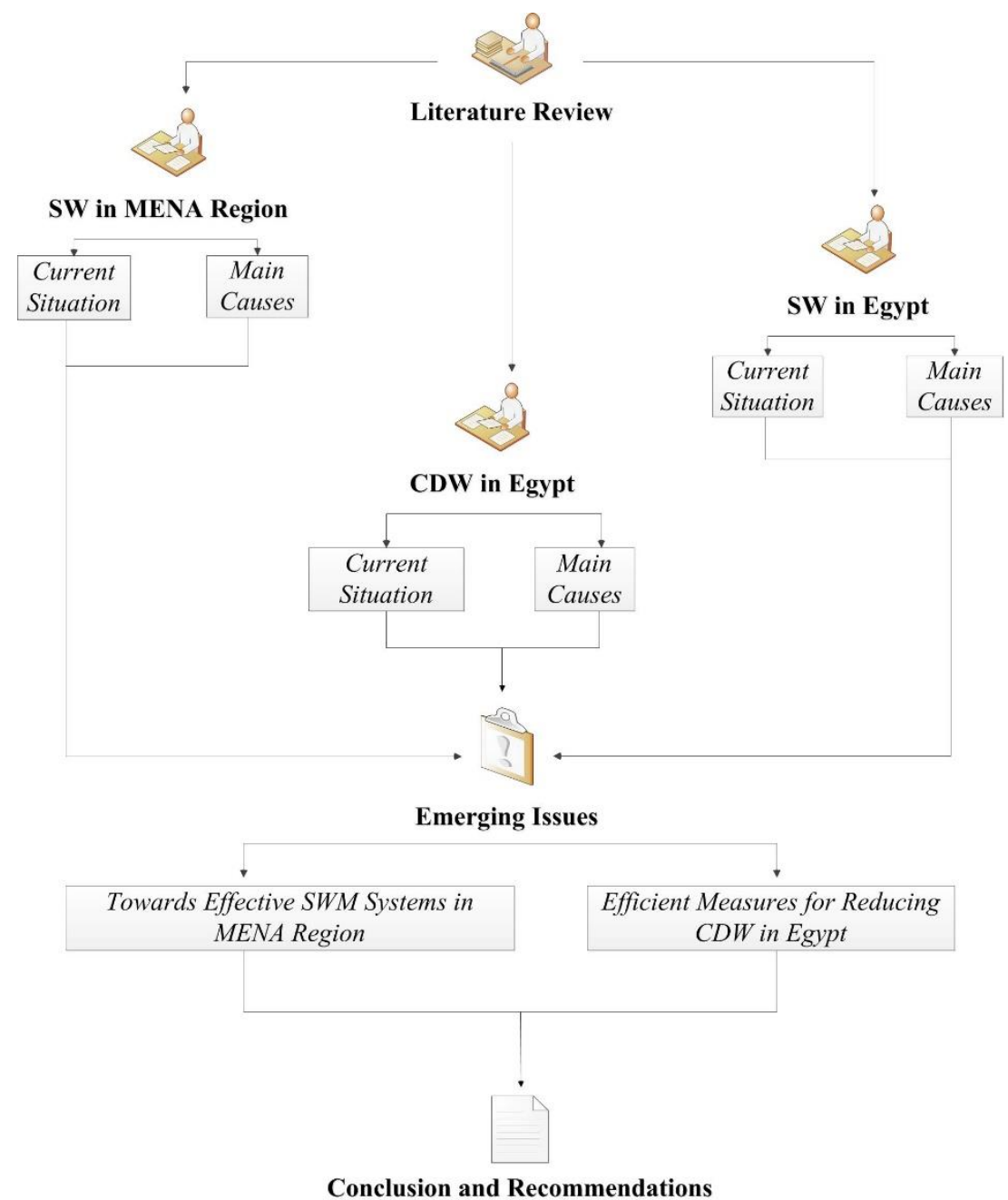

Figure 1. Research Framework for the Literature Review 


\section{The Solid Waste Problem in the MENA Region}

\section{The Current Situation in the MENA Region}

The MENA region contains about $6 \%$ of the total world's population. The total population of the region has boomed from around 100 million in 1950 to around 380 million in 2000. The total area of the MENA region is about 11.1 million $\mathrm{km}^{2}$. Most of the countries in the MENA region can be classified as developing countries except Saudi Arabia, the United Arab Emirates, Qatar, and Kuwait which are classified as developed countries (Nassour et al., 2016). There is a huge gap between developing countries and developed countries in terms of disposal and management of SW materials (Zyoud et al., 2015). The MENA region is noted for significant SW generation worldwide with a per capita municipal waste (MW) production more than $2 \mathrm{~kg}$ per day on average in most of its countries (Zafar, 2016).

By 2020, SW is expected to exceed 200 million tonnes annually due to population and economic growth, accelerated rate of urbanization, fast pace of industrialization, changing consumption patterns, and lack of public awareness (El-Sherbiny et al., 2011; Zyoud et al., 2015). MW is not the only or even the main reason for the SW problem in the MENA region, but CDW is the most influential and main component of SW in the MENA region. For 
instance, due to the high boom of construction activities among the Gulf Cooperation Council (GCC), 55\% of total SW was estimated to be generated from CD operations (Aden, 2017).

MENA cities spend between 20 to $50 \%$ of their budgets on solid waste management (SWM). Unfortunately, there is no proper management of SW. Despite the fact that $80 \%$ of the generated SW is decomposable; however, less than 5\% is recycled and less than $20 \%$ is properly treated. The cost of SW problem in the MENA region in terms of damage was equivalent to about 0.3\% to the total GDP in 2006 (El-Sherbiny et al., 2011; Arif and Abaza, 2012). The MENA's growing SW problem has started to urge officials and environmentalists to propose different solutions such as pay-as-you-throw policy (Aden, 2017). Most of the governments in the MENA region have recognised the SW problem and they want to apply adequate solutions (Nassour et al., 2016). The increasing environmental awareness nowadays in the region means that the environmental protection is on the political agenda.

However, the sector of SWM in the MENA region is unorganised and inefficient, and the different WM strategies are still in their initial phases (El-Sherbiny et al., 2011). Despite the expected increase in SW generation in the MENA region by 2020, research carried out on managing SW problem in the MENA region remains insufficient. A study carried out by Zyoud et al. (2015) indicated that a total of 382 research documents were published by authors in the MENA region in the SWM sector from 1982 up to 2012 and it was noted that 
the number of publications increased rapidly in the last 10 years of this period. The highest number of publications focused on Egypt, followed by Tunisia and Jordan, and the most productive institution in terms of publications over the MENA region was the American University of Beirut (AUB) in Lebanon. It was recognised that Egypt is leading the Arab countries in the SWM research.

\section{Main Causes of Solid Waste Problem in the MENA Region}

Different researchers have explored the main reasons for the SW problem in the MENA region. These reasons are divided into eight main clusters as a result of summarising and categorising the surveyed literature. The main reasons are tabulated and explained, where it needs further explanation, in Table 1.

Table 1. Different Reasons behind SW Problem in the MENA Region

\begin{tabular}{|c|c|c|}
\hline Main Reason & Further Explanation & References \\
\hline $\begin{array}{l}\text { Lack of strict measures and } \\
\text { actions in the SWM sector }\end{array}$ & $\begin{array}{l}\text { SWM is faced by shortage in waste } \\
\text { management legislation and poor } \\
\text { planning. There is a lack in } \\
\text { legislative frameworks, policies, } \\
\text { strategies, and enforced laws and }\end{array}$ & $\begin{array}{l}\text { UNEP, 2009; } \\
\text { El-Sherbiny et } \\
\text { al., 2011; Arif } \\
\text { and Abaza, } \\
\text { 2012; Zafar, }\end{array}$ \\
\hline
\end{tabular}




\begin{tabular}{|c|c|c|}
\hline Main Reason & Further Explanation & References \\
\hline & $\begin{array}{l}\text { regulations which may help in } \\
\text { mitigating and dealing sustainably } \\
\text { with the SW problem in the MENA } \\
\text { countries. }\end{array}$ & $\begin{array}{l}\text { 2016; Nassour } \\
\text { et al., } 2016 .\end{array}$ \\
\hline $\begin{array}{l}\text { Limited public awareness about } \\
\text { the environmental issues, WM } \\
\text { practices and waste reduction, } \\
\text { and sustainable living }\end{array}$ & $\begin{array}{l}\text { The public awareness is critically } \\
\text { needed to help in facing the } \\
\text { challenge of the growing waste } \\
\text { problem by changing habits and } \\
\text { taking personal responsibility of the } \\
\text { environmental protection. }\end{array}$ & $\begin{array}{l}\text { UNEP, 2009; } \\
\text { El-Sherbiny et } \\
\text { al., 2011; Zafar, } \\
\text { 2016; Aden, } \\
2017\end{array}$ \\
\hline $\begin{array}{l}\text { Dumping of SW in open and } \\
\text { uncontrolled spaces, deserts, and } \\
\text { water }\end{array}$ & $\begin{array}{l}\text { Dumping is the common action of } \\
\text { dealing with SW throughout the } \\
\text { MENA region leading to hazardous } \\
\text { environmental pollution. SW are } \\
\text { often burnt in the open-air wherever } \\
\text { the dumpsites exists leading to air } \\
\text { pollution. }\end{array}$ & $\begin{array}{l}\text { UNEP, } 2009 ; \\
\text { El-Sherbiny et } \\
\text { al., 2011; Zafar, } \\
\text { 2016; Nassour } \\
\text { et al., } 2016\end{array}$ \\
\hline
\end{tabular}




\begin{tabular}{|c|c|c|}
\hline Main Reason & Further Explanation & References \\
\hline $\begin{array}{l}\text { Lack of proper means of SW } \\
\text { collection, transport systems, and } \\
\text { balanced and adequate coverage } \\
\text { of WM }\end{array}$ & & $\begin{array}{l}\text { El-Sherbiny et } \\
\text { al., 2011; Zafar, } \\
2016\end{array}$ \\
\hline $\begin{array}{l}\text { Lack of integrated sustainable } \\
\text { SWM plans }\end{array}$ & $\begin{array}{l}\text { The MENA region lacks SWM } \\
\text { plans which focus on the main } 4 \mathrm{R} \text { 's } \\
\text { of waste minimisation strategies } \\
\text { (i.e., reduce, reuse, recycle, and } \\
\text { recover). There is no focus on the } \\
\text { prevention/reduction approach. } \\
\text { Also, the reuse, recycle, and recover } \\
\text { approaches are still at their infancy } \\
\text { stages in most of the MENA } \\
\text { countries. }\end{array}$ & $\begin{array}{l}\text { UNEP, } 2009 \text {; } \\
\text { El-Sherbiny et } \\
\text { al., 2011; Arif } \\
\text { and Abaza, } \\
\text { 2012; Zafar, } \\
\text { 2016; Nassour } \\
\text { et al., 2016; } \\
\text { Aden, } 2017\end{array}$ \\
\hline $\begin{array}{l}\text { Scarcity in reliable data of } \\
\text { hazardous waste and waste } \\
\text { producing activities in the region }\end{array}$ & $\begin{array}{l}\text { This data is needed to help in } \\
\text { developing proper policies and } \\
\text { efficient WM plans nationally and }\end{array}$ & $\begin{array}{l}\text { UNEP, 2009; } \\
\text { El-Sherbiny et } \\
\text { al., } 2011 \text {; }\end{array}$ \\
\hline
\end{tabular}




\begin{tabular}{|c|c|c|}
\hline Main Reason & Further Explanation & References \\
\hline & $\begin{array}{l}\text { regionally. Research is vital to } \\
\text { obtain reliable data and several } \\
\text { reasons are cited for the low number } \\
\text { of research publications as follows: } \\
\text { (1) lack of funding and freedom; (2) } \\
\text { lack of industry-academia and } \\
\text { government-academia partnerships; } \\
\text { (3) general weakness in scientific } \\
\text { writing; and (4) lack of research } \\
\text { promotion in the field of SWM. }\end{array}$ & $\begin{array}{l}\text { Nassour et al., } \\
2016\end{array}$ \\
\hline $\begin{array}{l}\text { Instability of political conditions } \\
\text { in the MENA region }\end{array}$ & $\begin{array}{l}\text { The unstable political conditions } \\
\text { hinder the development and } \\
\text { improvement of WM structures. }\end{array}$ & $\begin{array}{l}\text { UNEP, } 2009 ; \\
\text { El-Sherbiny et } \\
\text { al., 2011; Arif } \\
\text { and Abaza, } \\
\text { 2012; Nassour } \\
\text { et al., } 2016\end{array}$ \\
\hline
\end{tabular}




\begin{tabular}{l|l}
\hline \multicolumn{1}{c|}{ Main Reason } & \multicolumn{1}{c}{ Further Explanation } \\
\hline Others: insufficient allocated & UNEP, 2009 \\
funds, lack of coordination & ;El-Sherbiny et \\
among stakeholders, shortage of & al., 2011; Zafar, \\
trained and qualified personnel, & 2016; Nassour \\
and shortage in technical and & et al., 2016; \\
operational decision making & Aden, 2017 \\
\hline
\end{tabular}

\section{The Solid Waste Problem in Egypt}

\section{The Current Situation in Egypt}

As many countries in the MENA region, Egypt is facing a major challenge regarding the SW problem. The SW became a serious threat to Egypt which has to be handled properly and with effective solutions (El-Gamal, 2012). According to the latest report published by the Egyptian Ministry of Environment (EMoE), Egypt generates annually about 90 million tonnes of total SW as shown in Table 2, in which 55 thousand tonnes of waste are generated on a daily basis as MW (EMoE, 2017). About 21 million tonnes are generated as MW and 
about 5.8 million tonnes are generated as CDW (EMoE, 2017). CDW is ranked the fourth among eight main reasons of SW generation in Egypt.

Table 2. Classification of SW in Egypt

\begin{tabular}{c|c}
\hline Type of Solid Waste & Annual Generated Quantities (million tonnes) \\
\hline Municipal waste & 21 \\
\hline Agricultural waste & 31 \\
\hline Construction and demolition waste & 5.8 \\
\hline Industrial waste & 4.9 \\
\hline Hazardous waste & 0.54 \\
\hline Health-care waste & 0.52 \\
\hline Sludge and slurry waste & 2 \\
\hline Waste resulting from canals' and & 25 \\
drainages' purification & \\
\hline Total & 90.76 \\
\hline
\end{tabular}

Source: (EMoE, 2017)

In Egypt, the SWM system is weak and inefficient where $81 \%$ of generated SW are dumped on streets of residential areas and at illegal dumping sites without any treatment as indicated in Figure 2 (EMoE, 2017). In 2016, It was estimated that there were 18 million $\mathrm{m}^{3}$ 
of dumped SW inside the different Egyptian governorates, in which most of it was CDW mixed with MW (EMoE, 2017). Cairo governorate possessed the highest amount of these dumped SW with an estimated quantity equal to 5 million $\mathrm{m}^{3}$ out of the total 18 million $\mathrm{m}^{3}$ of SW as indicated in Table 3 (EMoE, 2017).

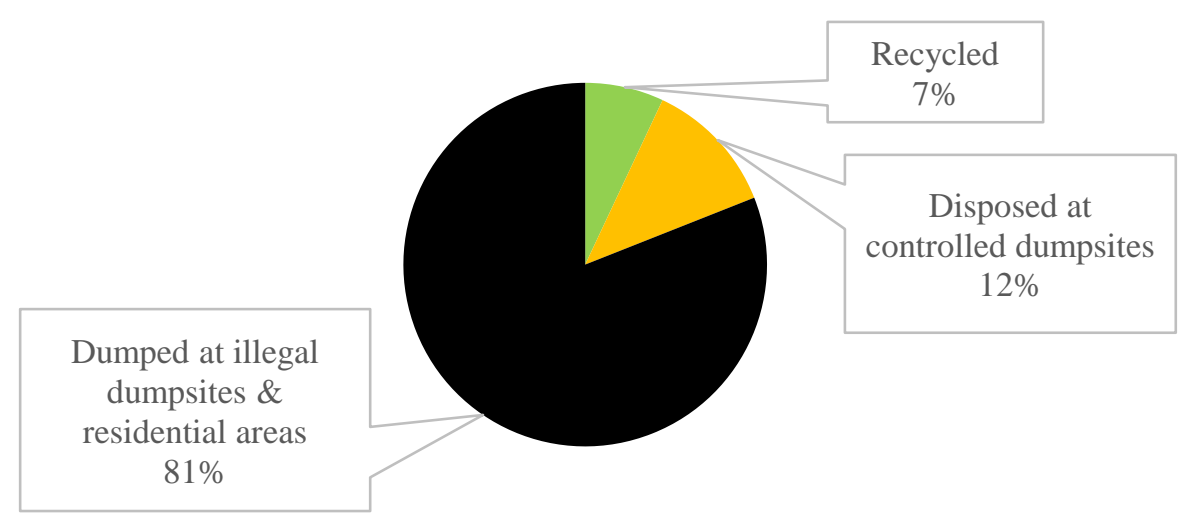

Figure 2. Current Status of SWM in Egypt

Source: (EMoE, 2017) 
Table 3. Dispersion of Dumped SW among Egyptian Governorates

\begin{tabular}{c|c}
\hline Governorate & Amount of Dumped SW (million $\mathbf{~ m}^{3}$ ) \\
\hline Cairo & 5.0 \\
\hline Alexandria & 0.15 \\
\hline Giza & 3.0 \\
\hline El-Qalyubia & 0.50 \\
\hline Dakahlia & 1.80 \\
\hline Gharbia & 0.30 \\
\hline Menofia & 1.20 \\
\hline El-Beheira & 0.60 \\
\hline Kafr El-Sheikh & 0.20 \\
\hline El-Sharkia & 0.30 \\
\hline Damietta & 0.40 \\
\hline Ismailia & 0.35 \\
\hline Port Said & 0.20 \\
\hline Suez & 0.50 \\
\hline El-Fayoum & 0.30 \\
\hline Beni Suef & 0.15 \\
\hline El-Minya & 0.90 \\
\hline Assiut & 0.25 \\
\hline Sohag & 0.28 \\
\hline Qena & 0.20 \\
\hline Aswan & 0.20 \\
\hline Luxor & 0.10 \\
\hline Red Sea & 0.80 \\
\hline Matrouh & 0.15 \\
\hline North Sinai & 0.10 \\
\hline South Sinai & 0.10 \\
\hline Total & 18 \\
\hline &
\end{tabular}

Source: (EMoE, 2017)

The waste recycling industry in Egypt has financial and technical deficiencies and it is not included in a legal framework. Moreover, most landfills, in which the SW is dumped in, are 
open and exposed as shown in Figure 3. Unfortunately, the common practice of dealing with the dumped SW is open burning instead of dealing adequately with the SW by recycling or sealing them within the landfills. Additionally, Egypt lacks the necessary equipment for covering SW ((Japanese Ministry of Environment (JMoE), 2004); El-Gamal, 2012; Zaki and Khial, 2014; Azmy and El Gohary, 2017)

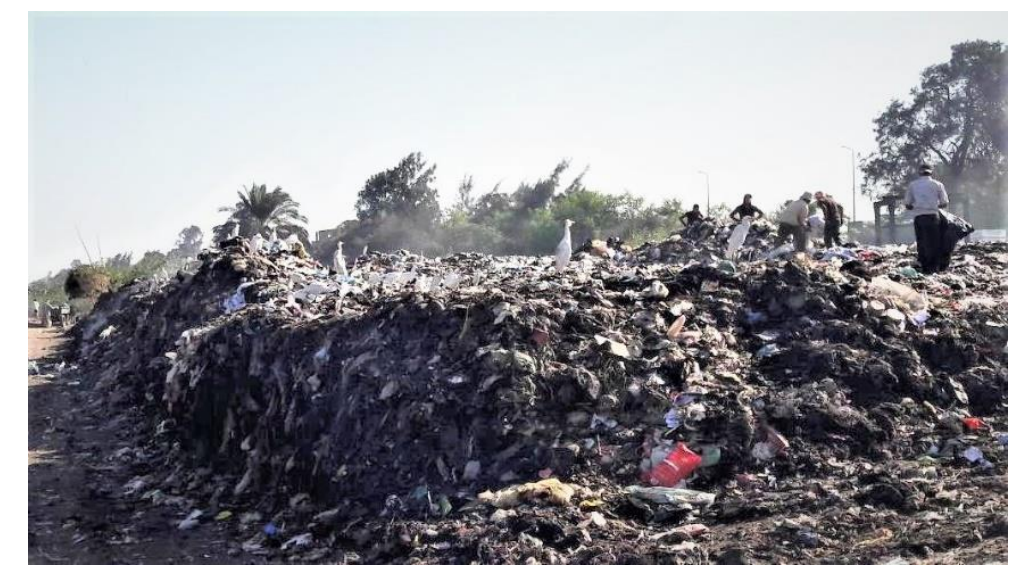

Figure 3. Uncontrolled Open Landfill in El-Sharkia Governorate in Egypt Source: (Sharkiatoday, 2017)

\section{Main Causes of Solid Waste Problem in Egypt}

At the local context of Egypt, the factors contributing to the inadequacy of SWM are similar to the aforementioned ones in the MENA region. Besides, additional factors were identified by El-Gamal (2012) and National Solid Waste Management Programme (NSWMP) (2014) 
as follows: (1) conflicts in institutional structure, undefined roles, and deficiency in capacities; (2) lack of monitoring and evaluation mechanisms; and (3) inadequate social inclusion in centralised planning. It is also increasingly recognised that CDW contributes significantly to the general problems of SWM.

One of the most critical problems existing in Egypt is that there are no specific laws and legislation for SWM. Legislation can be found as provisions within other laws. The legal framework of SWM in Egypt is dispersed into different pieces of legislation. These few pieces of legislation try to manage the process of SW transfer, charge, and dumping. Unfortunately, these legislation are not strictly enforced and led to a dominant practice of dumping SW in public areas and on streets (El-Gamal, 2012; Zaki and Khial, 2014; Elsaid and Aghezzaf, 2015; Ibrahim and Mohamed, 2016; ; EMoE, 2017; Azmy and El Gohary, 2017).

A SWM system can be explained as the management of all practices, legislation, procedures, processes, responsibilities, and resources for building a system that deals with SW efficiently and follow environmental regulations (Elsaid and Aghezzaf, 2015; Ibrahim and Mohamed, 2016). A SWM system may include strategies which can be applied to avoid or reduce waste generation as the most preferable way. A SWM system is considered sustainable if it is economically affordable, environmentally effective, and socially 
acceptable (Elsaid \& Aghezzaf, 2015). Unfortunately, Egypt lacks a sustainable SWM system to tackle the increasing SW problem.

\section{Construction and Demolition Waste Problem in Egypt}

\section{The Current Situation in Egypt}

The construction industry is noted for waste generation and polluting effect on the environment (Azis et al., 2012). In Egypt, waste in construction materials represents a severe problem to the construction industry (Garas et al., 2001). CDW is dumped on roads and in facilities which lack effective management as shown in Figure 4. Most of the dumping sites are unsafe and marked by non-existence of effective precautions to prevent the self-ignition of waste which lead to more environmental pollution (Abdelhamid, 2014; Azmy and El Gohary, 2017). 


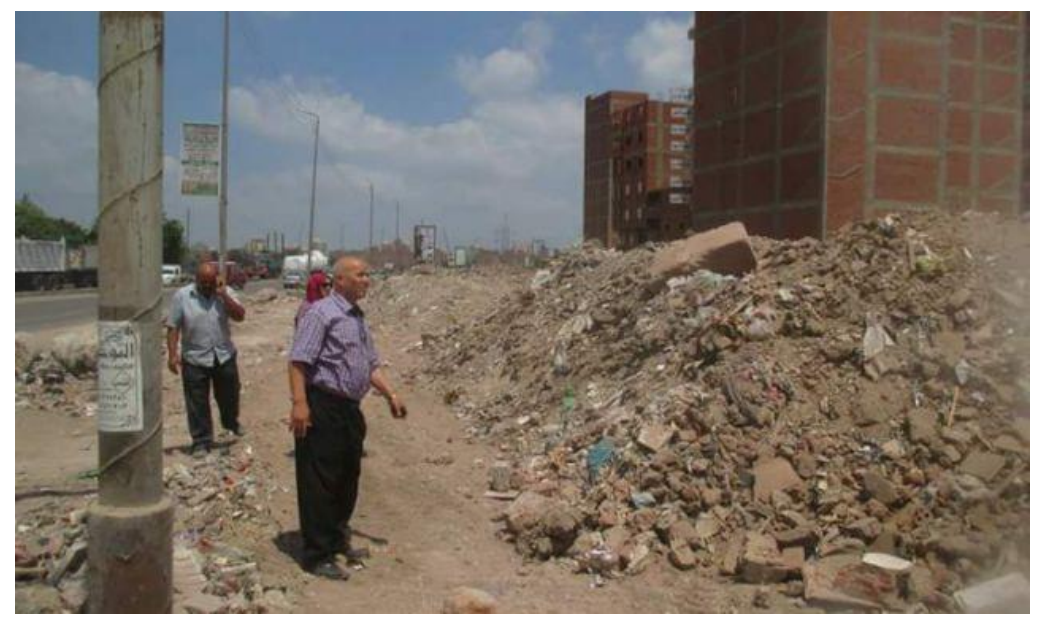

Figure 4. 300 Tonnes of CDW Dumped on Main Roads of Mansoura City Source: (Dot Msr, 2017)

The biodegradation of CDW in landfills results in serious health and environmental problems (Azmy and El Gohary, 2017). In addition, CDW negatively impacts the efficiency, effectiveness, value, and profitability of construction companies. CDW has a negative impact on countries' economies (Memon et al., 2015). Caldas et al. (2014) claimed that construction materials and equipment constitute between 50 and $60 \%$ of total project cost and affect $80 \%$ of its schedule. Although the Egyptian Environmental Law regulates CDW disposal, these regulations lack clauses which foster CDW reduction (Azmy \& El Gohary, 2017).

According to a recent study carried out by Hany and Dulaimi (2014) regarding the composition of CDW in Greater Cairo, it was found that timber is the highest wasted 
construction material as listed in Table 4 and represented in Figure 5. This is because it is used in framework and shuttering for concrete. Moreover, labours do not have the high skills needed for using new tools to minimise timber waste and there is a lack of using prefabricated elements which can reduce timber waste greatly (Hany and Dulaimi, 2014). It is worth mentioning that the statistics of SW generation and disposal in Egypt can be inaccurate due to lack of weighing facilities at disposal sites and the absence of SW sampling and analysis techniques (Zaki and Khial, 2014; Ibrahim and Mohamed, 2016).

Table 4. Percentages of CDW in Greater Cairo

\begin{tabular}{|l|l|}
\hline Type of Construction Material & Percentage of Waste \\
\hline Timber & $30-50 \%$ \\
\hline Sand & $15-20 \%$ \\
\hline Steel & $2-5 \%$ \\
\hline Cement & $4-5 \%$ \\
\hline Concrete & $3-4 \%$ \\
\hline Bricks & $4-6 \%$ \\
\hline Tiles & $4-6 \%$ \\
\hline Packaging/wrapping & $4-6 \%$ \\
\hline
\end{tabular}

Source: (Hany and Dulaimi, 2014) 


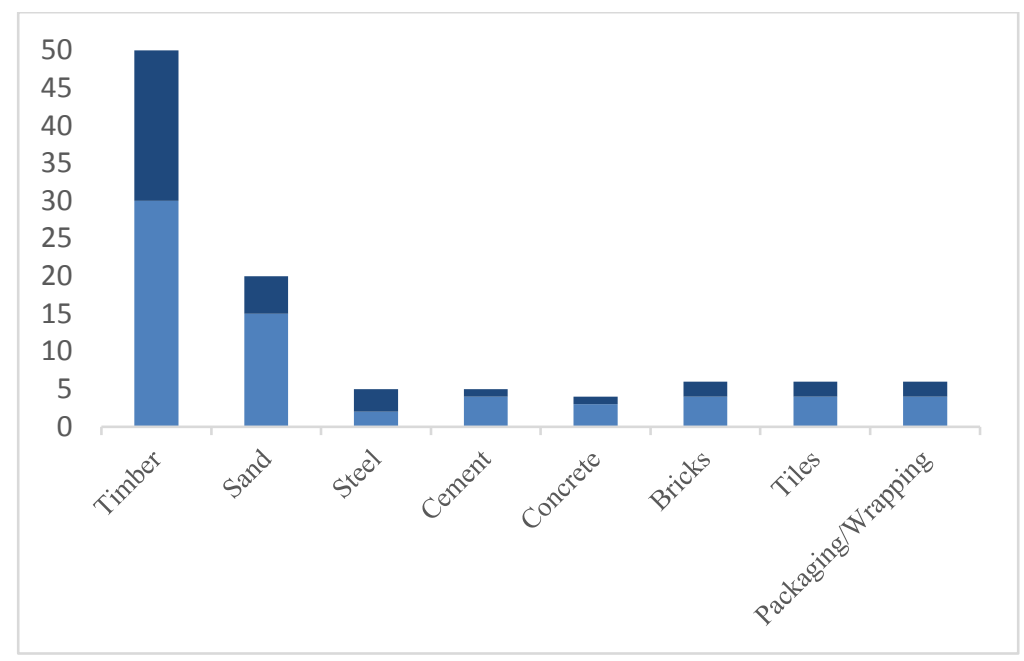

Figure 5. Patterns of CDW generated in Greater Cairo

Main Causes of Construction and Demolition Waste Problem in Egypt

In addition to the aforementioned causes of SW problem in the MENA region and Egypt, the behaviour of the Egyptian construction industry towards CDW has not improved for a long time resulting in a rapid and continuous increase of CDW generation (Hany and Dulaimi, 2014; Azmy and El Gohary, 2017). Based on the SW statistics in 2016, it is worth mentioning that CDW represented about $6.4 \%$ of the total generated SW in Egypt (EMoE, 2017). SW statistics in 2012 showed that CDW represented about $4.5 \%$ of the total generated SW in Egypt (Zaki and Khial, 2014). This proves that the boom of construction is associated with more waste generation. Nowadays, the Egyptian government is executing a lot of 
megaprojects following the political agenda of Egypt vision 2030 such as National Project for the Development of Sinai, National Projects for Roads, National Project for the Development of Upper Egypt, Establishment of New Cities, and The Golden Triangle Project (Invest-gate, 2016). It has been claimed that the increasing demand for executing megaprojects will necessarily require the use of more materials and resources which consequently will lead to generation of more CDW (Azis et al., 2012; Nagapan et al., 2012; Foo et al., 2013; Ahmad et al., 2014).

Moreover, there are few legislation which manage CDW in Egypt (Zaki \& Khial, 2014). Article 39 of the Environment Law 4/1994 and Article 41 of the executive regulations (Prime Minister Decree Number 338/1995) regulate CDWM. They require that all personnel engaged in exploration, excavation, and $\mathrm{CD}$ activities should take necessary precautions to store, transport, and dispose the waste generated by these activities in a safe manner. These articles include the specifications and allow local authorities to include these specifications in the permits issued for the exploration, excavation, and CD activities. Moreover, Laws 106/1976 and 101/1996 authorise local governments to involve CDWM in the permits needed for construction activities. Also, these laws authorise local governments to gather fees from contractors and owners to provide or pay for CDW collection and/or disposal. 
However, contractors usually find it cheaper to transfer CDW to a nearby illegal site and neglect paid-for disposal services at an approved legal site.

In addition to the scarcity in legislation of CDWM, these few legislation are ineffective due to several reasons as follows: (1) the existence of construction operations without a permit; (2) lack of regulations' enforcement in Egypt; (3) CDW collection and disposal is carried out by limited number of local governments; and (4) the $1 \%$ building permit fee is dedicated to other services rather than CDWM (Zaki \& Khial, 2014). The lack of enforced environmental legislation and laws negatively affects the WM system as people are not liable to comply with weak regulations. Moreover, the responsibility of SWM in Egypt is scattered among a number of authorities within the central government which leads to conflicts in roles and responsibilities (El-Gamal, 2012; Zaki and Khial, 2014; Elsaid and Aghezzaf, 2015; EMoE, 2017; Azmy and El Gohary, 2017).

\section{Emerging Issues in MENA region and the Egyptian Construction Industry}

Towards Effective Solid Waste Management Systems in the MENA region

After critically reviewing the literature, there are some emerging issues at the global and regional (i.e., MENA) levels regarding the SW problem which is becoming more severe and challenging. According to the study carried out by Transparency Market Research in 2017, 
global attention has to focus on the $3 \mathrm{R}$ policies of reduce, reuse, and recycle in order to reduce the amount of compiled CDW (Slowey, 2018). Different policies have been formulated to promote the application of the $3 \mathrm{R}$ policies of dealing with CDW. There are also various certifications, such as LEED and BREEAM, in place in different countries to encourage the proper CDWM.

According to lessons learnt from developed countries, there are two main approaches in tackling the problem of SW as follows: (1) by investing allocated funds to use advanced technologies in order to maximise SW diversion from landfills while gradually applying the $3 \mathrm{R}$ policies; or (2) by starting with the $3 \mathrm{R}$ policies to gradually reroute the $\mathrm{SW}$ away from landfills and avoid the dumping of SW. The second approach is the most convenient approach for the developing countries, such as MENA countries, due to limited available capital (El-Sherbiny et al., 2011). The most convenient way of dealing with SW, for the environmental and economic benefits, is to minimise generating it at its source. This is the reason that waste reduction is at the top of the well-known waste management hierarchy and the main goal of waste reduction is to disconnect the economic growth from the negative environmental impacts caused by generated waste, often referred to as "decoupling" (Aden, 2017). 
Several researchers suggested various approaches in structuring SWM sectors in order to solve the SW problem in the MENA region. These approaches are divided into eight main clusters as a result of summarising and categorising the surveyed literature. The main approaches are tabulated and explained, where it needs further explanation, in Table 5.

Table 5. Different Approaches for Solving SW Problem in the MENA Region

\begin{tabular}{|c|c|c|}
\hline Main Approach & Further Explanation & References \\
\hline Adoption of WM hierarchy & $\begin{array}{l}\text { MENA Governments should encourage the } \\
\text { different business sectors to adopt the WM } \\
\text { hierarchy with a special focus on waste } \\
\text { reduction approach by offering incentives. }\end{array}$ & $\begin{array}{l}\text { UNEP, 2009; } \\
\text { El-Sherbiny } \\
\text { et al., 2011; } \\
\text { Arif and } \\
\text { Abaza, 2012; } \\
\text { Aden, } 2017\end{array}$ \\
\hline $\begin{array}{l}\text { Boosting public awareness } \\
\text { of citizens }\end{array}$ & $\begin{array}{l}\text { MENA governments should increase the } \\
\text { public awareness of their citizens by } \\
\text { implementing green behaviours in their } \\
\text { societies and let them know the } \\
\text { consequences of inadequate WM. This can } \\
\text { be achieved through different }\end{array}$ & $\begin{array}{l}\text { UNEP, 2009; } \\
\text { El-Sherbiny } \\
\text { et al., 2011; } \\
\text { Zafar, 2016; } \\
\text { Aden, } 2017\end{array}$ \\
\hline
\end{tabular}




\begin{tabular}{|c|c|c|}
\hline Main Approach & Further Explanation & References \\
\hline & $\begin{array}{l}\text { governmental strategies as follows: (1) } \\
\text { promote public awareness campaigns; (2) } \\
\text { implement a "Clean Week" in which the } \\
\text { public, service providers, and government } \\
\text { officials participate in SWM activities; (3) } \\
\text { foster a "Clean City" competition with } \\
\text { financial incentives to encourage } \\
\text { municipalities to act; (4) establish } \\
\text { educational content about SWM in } \\
\text { schools" curriculum; and (5) increase the } \\
\text { awareness about SWM at the work place of } \\
\text { large waste generators. }\end{array}$ & \\
\hline $\begin{array}{l}\text { Developing policies, } \\
\text { enforceable laws, strategic } \\
\text { plans, and legislative and } \\
\text { institutional frameworks }\end{array}$ & $\begin{array}{l}\text { MENA governments should take this } \\
\text { action to support the adoption of integrated } \\
\text { sustainable SWM plans. This can be } \\
\text { achieved by different governmental } \\
\text { strategies such as follows: (1) consider the }\end{array}$ & $\begin{array}{l}\text { UNEP, 2009; } \\
\text { El-Sherbiny } \\
\text { et al., 2011; } \\
\text { Arif and } \\
\text { Abaza, 2012; }\end{array}$ \\
\hline
\end{tabular}




\begin{tabular}{|c|c|c|}
\hline Main Approach & Further Explanation & References \\
\hline & $\begin{array}{l}\text { SWM sector in the country's national } \\
\text { development plan; (2) develop national } \\
\text { guidelines for SWM; (3) construct a } \\
\text { national SW task force to follow the } \\
\text { progress of the SWM plans and guidelines; } \\
\text { (4) identify the deficiencies in the current } \\
\text { laws and regulations for SWM; and (5) } \\
\text { develop specific laws for regulating } \\
\text { CDWM. }\end{array}$ & $\begin{array}{l}\text { Zafar, 2016; } \\
\text { Nassour et } \\
\text { al., } 2016\end{array}$ \\
\hline $\begin{array}{l}\text { Promoting the industrial } \\
\text { sector to adopt sustainable } \\
\text { production practices }\end{array}$ & & $\begin{array}{l}\text { UNEP, 2009; } \\
\text { El-Sherbiny } \\
\text { et al., 2011; } \\
\text { Aden, } 2017\end{array}$ \\
\hline $\begin{array}{l}\text { Establishing a reliable } \\
\text { database for SW in MENA } \\
\text { countries }\end{array}$ & $\begin{array}{l}\text { This is needed to document the current } \\
\text { status of the SW problem in the MENA } \\
\text { region in order to introduce appropriate } \\
\text { solutions and strategies for solving it. This }\end{array}$ & $\begin{array}{l}\text { UNEP, 2009; } \\
\text { El-Sherbiny } \\
\text { et al., 2011; }\end{array}$ \\
\hline
\end{tabular}




\begin{tabular}{|c|c|c|}
\hline Main Approach & Further Explanation & References \\
\hline & $\begin{array}{l}\text { can be achieved through different } \\
\text { government strategies as follows: (1) } \\
\text { develop mechanisms for gathering } \\
\text { information on SW quantities and } \\
\text { compositions on the national level; (2) set } \\
\text { up an operational and environmental } \\
\text { monitoring program in each SW facility; } \\
\text { (3) unify the practices for gathering SW } \\
\text { data among the solid waste facilities within } \\
\text { the country and among the MENA region; } \\
\text { and (4) establish a government-run SW } \\
\text { website and upload SW data on it regularly. }\end{array}$ & $\begin{array}{l}\text { Nassour } \\
\text { al., } 2016\end{array}$ \\
\hline $\begin{array}{l}\text { Promoting the mutual } \\
\text { cooperation in research and } \\
\text { development (R\&D) } \\
\text { between MENA countries }\end{array}$ & $\begin{array}{l}\text { MENA governments need this step to help } \\
\text { in exchanging knowledge and experience } \\
\text { in the sector of SWM. }\end{array}$ & $\begin{array}{l}\text { UNEP, 2009; } \\
\text { El-Sherbiny } \\
\text { et al., 2011; } \\
\text { Arif and } \\
\text { Abaza, 2012; }\end{array}$ \\
\hline
\end{tabular}




\begin{tabular}{|c|c|c|}
\hline Main Approach & Further Explanation & References \\
\hline & & $\begin{array}{l}\text { Nassour et } \\
\text { al., } 2016\end{array}$ \\
\hline $\begin{array}{l}\text { Developing financial } \\
\text { frameworks for solid waste } \\
\text { management }\end{array}$ & $\begin{array}{l}\text { This is needed to allocate adequate funds } \\
\text { for efficient management of solid waste, } \\
\text { and to consider user-pays, polluter-pays, } \\
\text { and landfill taxing principles. A sustainable } \\
\text { financial plan should be developed for solid } \\
\text { waste management which has an allocated } \\
\text { budget separate from the total budget to } \\
\text { identify the total cost of solid waste } \\
\text { management. }\end{array}$ & $\begin{array}{l}\text { UNEP, 2009; } \\
\text { El-Sherbiny } \\
\text { et al., 2011; } \\
\text { Zafar, 2016; } \\
\text { Nassour et } \\
\text { al., } 2016\end{array}$ \\
\hline $\begin{array}{l}\text { Developing institutional } \\
\text { capacity of municipalities } \\
\text { on solid waste management } \\
\text { by investing in people, } \\
\text { institutions, and practices. }\end{array}$ & $\begin{array}{l}\text { This can be achieved through different } \\
\text { strategies to be adopted by MENA } \\
\text { governments as follows: (1) implement } \\
\text { training and educational programs about } \\
\text { solid waste management and governance } \\
\text { including officials from central and }\end{array}$ & $\begin{array}{l}\text { UNEP, 2009; } \\
\text { El-Sherbiny } \\
\text { et al., 2011; } \\
\text { Arif and } \\
\text { Abaza, 2012; } \\
\text { Zafar, 2016; }\end{array}$ \\
\hline
\end{tabular}




\begin{tabular}{|c|c|c|}
\hline Main Approach & Further Explanation & References \\
\hline & $\begin{array}{l}\text { regional governments; (2) arrange } \\
\text { information exchange trips for solid waste } \\
\text { officials in the MENA region to share their } \\
\text { experiences and knowledge, improve } \\
\text { policies, and learn about new green } \\
\text { techniques and practices; (3) implement } \\
\text { solid waste management educational and } \\
\text { research programs at universities; and (4) } \\
\text { assign funds for capacity building in solid } \\
\text { waste management. }\end{array}$ & $\begin{array}{l}\text { Nassour et } \\
\text { al., } 2016 ; \\
\text { Aden, } 2017\end{array}$ \\
\hline
\end{tabular}

Efficient measures for Reducing Construction and Demolition Waste in the Egyptian

Construction industry

In order to reduce the negative impacts of CDW on the TBL of sustainability, the usage of materials should be rationalised through guidelines and standards indicating how to procure and use materials in a sustainable manner (Hany and Dulaimi, 2014; Abdelhamid, 2014). A number of visions, strategies, technological methods, and action plans have been developed 
over the years to reduce CDW problem during design and construction phases of a project. They included for instance: Industrialisation, Computer Integrated Construction, Constructability, Partnership, Robotized and Automated Construction, Lean Construction (LC), Building Information Modelling (BIM), Value Engineering (VE), Green Building (GB) practices, and Sustainable Supply Chain Management (SSCM) (Hussin et al., 2013; Marhani et al., 2013; Othman et al., 2014). These different approaches may help in reducing the generation of CDW up to $70 \%$ (Hussin et al., 2013). In spite of the valuable contribution of these solutions, the performance of the Egyptian construction industry is considered inefficient and poor in adopting these solutions in CDWM (Abdelhamid, 2014).

Despite the fact that CDW occurs during the construction activities on site, it is believed that it occurs due to various actions and activities at design, materials procurement, and construction stages of a project. In spite of the literature is very rich on the design and construction strategies for minimising CDW as aforementioned, few efforts have been exerted to investigate materials procurement measures to reduce CDW generated on site (Ajayi et al., 2017a). Zeb et al. (2015) defined procurement as "purchasing of materials, equipment, labour and services needed for execution of a project. Procurement is organising the purchasing and scheduling delivery of materials to the suppliers". Despite the fact that different studies (Formoso et al., 2002; Ajayi et al., 2017b) clearly stated that ineffective 
application of materials procurement process is a main cause of CDW generation, materials procurement measures for CDW reduction have neither been explored nor subjected to focused findings. As effective materials procurement process is efficient in reducing CDW as well as total cost of construction projects, it is important that research attention is also be focused on waste-efficient materials procurement process.

Daoud et al. (2018b) investigated the relationship between waste-efficient materials procurement and CDW minimisation. It was concluded that efficient materials procurement measures could help in minimising CDW and financial loss of projects. According to a study carried out in the UK by Fadiya et al. (2014), it is claimed that inefficient materials procurement, among other eight factors, contributes about $11.2 \%$ towards total generated CDW as shown in Figure 6. Also, Ajayi et al. (2017a) claimed that materials procurement is responsible for purchasing the wasted materials, and it was also claimed that materials procurement contributes up to $50 \%$ of the total project cost. Accordingly, Ajayi et al. (2017a) defined four clusters of materials procurement measures which could help in CDW minimisation as follows: (1) suppliers' low waste commitment; (2) low waste purchase management; (3) effective materials delivery management; and (4) waste efficient bill of quantity. Each cluster consists of a series of defined measures which should be applied to minimise CDW as summarised in Table 6. 


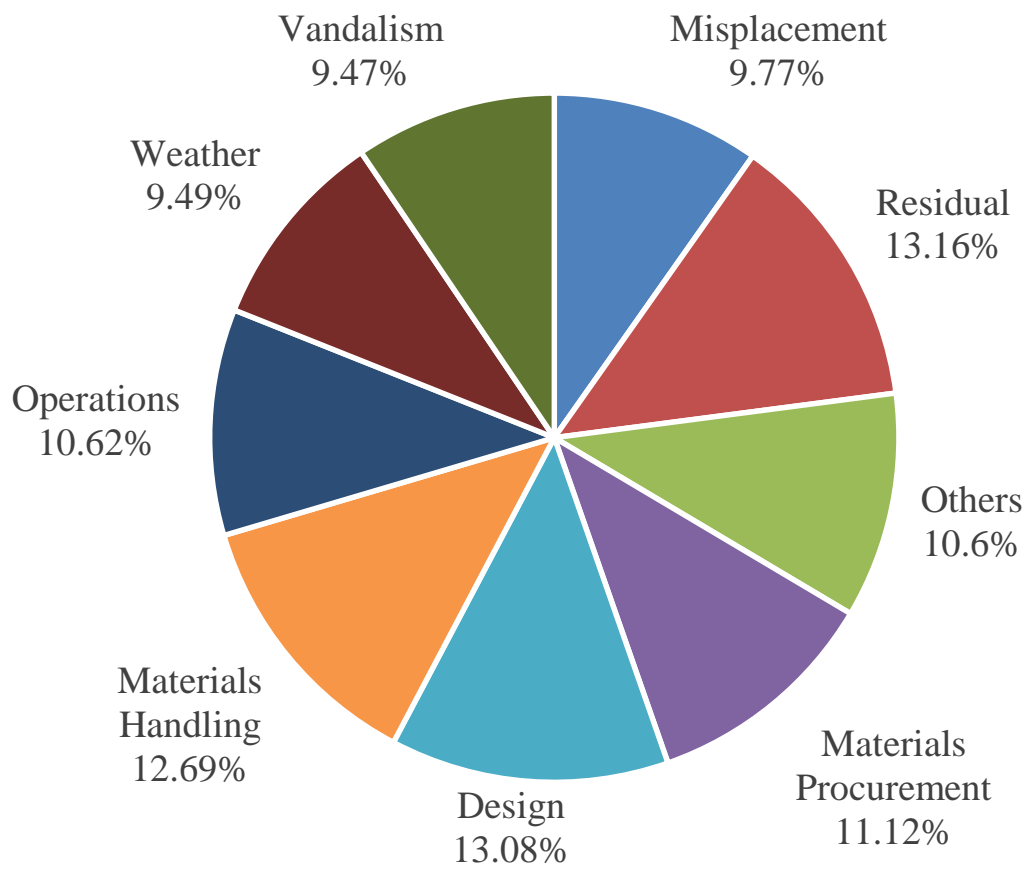

Figure 6. Different Factors Contributing to CDW Generation in the UK

Source: (Fadiya et al. 2014)

Table 6. Different Waste-efficient Materials Procurement Measures for Reducing CDW

\begin{tabular}{l|l}
\hline \multicolumn{1}{c|}{ Main Cluster } & \multicolumn{2}{c}{ Measures of Waste-efficient Materials Procurement } \\
Suppliers' low waste & $\bullet \begin{array}{l}\text { Suppliers' flexibility in supplying small quantities or } \\
\text { modification to products in conformity } \\
\bullet \text { Commitment to take back scheme (packaging, unused, } \\
\text { reusable and recyclable materials) }\end{array}$ \\
\hline
\end{tabular}




\begin{tabular}{|c|c|}
\hline Main Cluster & Measures of Waste-efficient Materials Procurement \\
\hline & $\begin{array}{l}\text { - Supply of quality and durable products } \\
\text { - Usage of minimal packaging (without affecting materials } \\
\text { safety) }\end{array}$ \\
\hline $\begin{array}{l}\text { Low waste purchase } \\
\text { management }\end{array}$ & $\begin{array}{l}\text { - Procurement of waste-efficient materials/technology (pre- } \\
\text { - Purchase of secondary materials (recycled and reclaimed) } \\
\text { - Purchase of quality and suitable materials } \\
\text { - Avoidance of variation orders } \\
\text { - Correct materials purchase }\end{array}$ \\
\hline $\begin{array}{l}\text { Effective materials } \\
\text { delivery management }\end{array}$ & $\begin{array}{l}\text { - Effective protection of materials (during transportation, } \\
\text { loading \& unloading) } \\
\text { - Effective onsite access (for ease of delivery) } \\
\text { - Efficient delivery schedule } \\
\text { - Usage of Just in Time (JIT) delivery system }\end{array}$ \\
\hline $\begin{array}{l}\text { Waste efficient bill of } \\
\text { quantity }\end{array}$ & $\begin{array}{l}\text { - Accurate materials take-off } \\
\text { - Prevention of over/under ordering }\end{array}$ \\
\hline
\end{tabular}




\begin{tabular}{l|l}
\hline Main Cluster & Measures of Waste-efficient Materials Procurement \\
\hline & $\bullet$ Reduced waste allowance \\
\hline
\end{tabular}

Source: (Ajayi et al., 2017a)

Another approach for rationalising and optimising materials procurement is applying GB practices through defined guidelines named green building rating systems (GBRSs) (Daoud et al., 2018a). One of the main goals of the GBRSs is to rationalise and optimise the usage of materials to reduce both $\mathrm{CDW}$ and total project cost by setting several measures for sustainable procurement of construction materials. It is worth mentioning that Egypt has it is own GBRS, named Green Pyramid Rating System (GPRS), which indicates the guidelines and standards for GB practices including green and sustainable procurement of construction materials (Daoud et al., 2018a). A category named Materials and Resources (M\&R) in the GPRS is responsible for indicating how to procure construction materials sustainably and in a green manner through several defined criteria as shown in Table 7 (Housing and Building National Research Center (HBRC), 2011; HBRC, 2017). However, Daoud et al. (2018a) argued that the GPRS still needs improvement and development especially its M\&R category. Also, it is not widely applied in Egypt due to several barriers such as economic issues, attitude and market, and technology and training. Moreover, Ismaeel et al. (2018) stated that Egyptian GPRS certification is not included in Egypt's national building law 
which makes the green approach of materials procurement unfamiliar to most of the practitioners in the Egyptian construction industry.

Table 7. Different Criteria of the M\&R Category Listed in the GPRS

\begin{tabular}{|c|c|}
\hline Main Criteria & Requirements and Options \\
\hline $\begin{array}{l}\text { Renewable Materials and } \\
\text { Materials Manufactured Using } \\
\text { Renewable Energy }\end{array}$ & $\begin{array}{l}\text { - Option 1: using at least one construction material } \\
\text { which is obtained from renewable resources such } \\
\text { as natural stones, earth, etc. } \\
\text { - Option 2: using at least one construction material } \\
\text { which is manufactured using renewable energy } \\
\text { sources such as solar energy, wind energy to } \\
\text { reduce } \mathrm{CO} 2 \text { emission }\end{array}$ \\
\hline $\begin{array}{l}\text { Regionally Procured Materials } \\
\text { and Products }\end{array}$ & $\begin{array}{l}\text { Credit points are gained when construction materials } \\
\text { and products value have been extracted or } \\
\text { manufactured within a distance of } 500 \mathrm{~km} \text { of the } \\
\text { project site with no less than } 50 \% \text { of the total } \\
\text { materials value based on cost }\end{array}$ \\
\hline $\begin{array}{l}\text { Reduction of Overall Material } \\
\text { Use }\end{array}$ & $\begin{array}{l}\text { - Option 1: using standard assemblies and reducing } \\
\text { customised spaces }\end{array}$ \\
\hline
\end{tabular}




\begin{tabular}{|c|c|}
\hline Main Criteria & Requirements and Options \\
\hline & $\begin{array}{l}\text { - Option 2: using materials that does not need } \\
\text { finishing } \\
\text { - Option 3: using materials that possess high } \\
\text { durability and require low maintenance }\end{array}$ \\
\hline $\begin{array}{l}\text { Alternative Building } \\
\text { Prefabricated Elements }\end{array}$ & $\begin{array}{l}\text { Credit points are gained for utilising totally or } \\
\text { partially prefabricated elements. The quantity of } \\
\text { prefabricated elements should not be less than } 10 \% \text { of } \\
\text { the total element quantity. These prefabricated } \\
\text { elements are used to reduce the need for construction } \\
\text { skills and reduce materials waste }\end{array}$ \\
\hline $\begin{array}{l}\text { Environment - Friendly, Sound } \\
\text { and Thermal Insulation Materials }\end{array}$ & $\begin{array}{l}\text { Credit points are obtained for using materials which } \\
\text { satisfy specific requirements as follows: 1) free from } \\
\text { chlorofluorocarbons, 2) does not release toxic fumes } \\
\text { when burned, 3) the percentage of volatile organic } \\
\text { compound is less than } 0.1,4 \text { ) thermal insulation } \\
\text { materials should have an ozone depleting materials of }\end{array}$ \\
\hline
\end{tabular}




\begin{tabular}{l|l}
\hline Main Criteria & \multicolumn{1}{c}{ Requirements and Options } \\
\hline & zero and a low global warming potential which does \\
& not exceed 5 \\
\hline
\end{tabular}

Source: (HBRC, 2017)

To foster the application of GPRS in the Egyptian construction industry, Daoud et al. (2018a) presented several recommendations as follows: (1) implementing GB principles extensively in construction education at universities across Egypt to boost their application and increase the awareness towards the negative impact of CDW on the TBL of sustainability; (2) setting a minimum score of GPRS certification as an obligation for issuing building's permits like what has been done by several countries such as UK, Japan, and United Arab Emirates; (3) introducing incentives for construction companies which apply GB principles; and (4) implementing green construction technologies and green procurement methodologies by construction companies within its projects and encourage their clients and employees to follow and implement them.

\section{Conclusion and Recommendations}

The construction industry plays a significant role in the development of societies. It leads to great developments in the economic and social sectors of nations. However, the negative environmental impacts of CD activities globally is non-negligible. The worldwide countries 
are suffering from the environmental hazards caused by the CDW, which consequently affects the lives of citizens. Focusing on the SW problem in the MENA region, the current situation is very critical and it may get worse year after year given the fact that most of the MENA countries are developing countries. It is claimed that the MENA region is expected to generate 200 million tonnes of SW annually by 2020 in which CDW constitutes the majority of its components.

The main reasons behind the SW problem in the MENA region were investigated based on the explored literature. Examples of these reasons are: (1) lack of strict legislation, policies, strategies, and enforced laws; (2) shortage in public awareness towards environmental issues, WM practices and waste reduction, and sustainable living; (3) dominance of unsustainable practices by dumping SW; (4) lack of sustainable WM policies (i.e., reduce, reuse, and recycle); and (5) lack of sufficient allocated funds, lack of coordination among stakeholders, shortage of trained and qualified personnel, and shortage in technical and operational decision making.

Based on the explored literature, different proposed solutions were investigated to solve the SW problem in the MENA region. Examples of these solutions are: (1) developing effective legislation, policies, strategies, and enforced laws; (2) increasing the public awareness of citizens about WM and sustainability; (3) encouraging the industrial sector to 
apply sustainable production practices; (4) encouraging different business sectors to apply WM hierarchy by offering incentives; (5) allocating sufficient funds for SWM; and (6) developing institutional capacity on SWM at the municipal level by investing in people, institutions, and practices.

Considering the CDW problem in the Egyptian construction industry, the situation is critical given the continuous unprofessional way of dealing with CDW by dumping on streets, residential areas, and at illegal dumping sites. This illegal dumping of CDW has severe negative effects on the TBL of sustainability. Moreover, the Egyptian laws which manage CDW are considered poor, weak, and ineffective towards the reduction of CDW. According to a study carried out on CDW in Greater Cairo, it was found that timber is the most wasted construction material. The main reasons behind this are: (1) extensive use of timber in framework and shuttering for concrete; (2) lack of high skills needed for using new tools to reduce wastage in timber; and (3) lack of using prefabricated elements which can minimise wastage in timber.

The literature review revealed different methodologies and strategies which could help greatly in minimising CDW in the Egyptian construction industry. Examples of these methods are: Industrialisation, Computer Integrated Construction, Constructability, Partnership, Robotized and Automated Construction, BIM, and GB practices. These 
strategies mainly focus on minimising CDW during design and construction stages. But, few researches focused on minimising waste during materials procurement stage, which is a critical interface between design and construction stages. It has been proven that proper materials procurement process could reduce both $\mathrm{CDW}$ and total project cost. The literature review revealed four different clusters of waste-efficient materials procurement measures which could help in minimising CDW as follows: (1) suppliers' low waste commitment; (2) low waste purchase management; (3) effective materials delivery management; and (4) waste efficient bill of quantity.

Additionally, GB practices is one of the main approaches to optimise and rationalise materials procurement in Egypt via applying the Egyptian GPRS. The criteria listed in M\&R category of the GPRS is responsible for guiding the sustainable and green procurement of construction materials leading to a reduction in CDW on the Egyptian construction sites. These criteria focus on: (1) using renewable materials and materials manufactured using renewable energy; (2) using regionally procured materials and products; (3) reducing overall materials use; (4) using alternative building prefabricated elements; and (5) using environment-friendly, sound and thermal insulation materials. However, the GPRS is faced by some limitations and barriers which hinder its proper application in the Egyptian construction industry. The application of the GPRS in the Egyptian construction industry can 
be fostered by: (1) including the GPRS certification with a minimum score in Egypt's national building law; (2) providing financial incentives for applying GB practices; and (3) implementing the education of GB practices at universities.

This review, as a part of a current $\mathrm{PhD}$ research project, contributes to the existing body of knowledge by investigating the current status of SW and CDW problems in the MENA region and the Egyptian context respectively. Future research in this $\mathrm{PhD}$ project will contribute to addressing the key gaps identified in the literature review and make an original contribution to the existing body of knowledge to benefit construction industry practitioners, government policymakers, and academics. At the industry level, the research will provide a conceptual framework which can guide the practitioners and professional organisations in the Egyptian construction industry on adopting key measures for waste-efficient materials procurement practices to minimise CDW. Furthermore, it will assist the Government of Egypt by providing recommendations and policy guidance for the improvement of current practices, legislation, behaviour, culture, and awareness necessary to address CDW problem. At the academic level, the research will provide a better understanding of how waste-efficient materials procurement practices can contribute to reducing CDW. Moreover, it will encourage more research on waste-efficient materials procurement practices as a research area for CDWM rather than the predominant focus only on design and construction strategies. 


\section{References}

Abdelhamid, M. S. (2014) Assessment of different construction and demolition waste management approaches, HBRC Journal, $10 \quad$ (3), pp. 317-326. DOI:10.1016/j.hbrcj.2014.01.003.

Aden, A. (2017) Waste Prevention in Middle East - Prospects and Challenges | EcoMENA. Available from: https://www.ecomena.org/waste-prevention/ [Accessed 27 June 2018].

Ahmad, A. C., Husin, N. I., Zainol, H., Tharim, A. H. A., Ismail, N. A. and Wahid, A. M. A. (2014) The Construction Solid Waste Minimization Practices among Malaysian Contractors, in: Mydin, M. A. O. and Salim, N. A. A. (eds.) Building Surveying, Facilities Management and Engineering Conference (BSFMEC 2014). Perak: EDP Sciences,15, pp. 249-257.

Ajayi, S. O., Oyedele, L. O., Akinade, O. O., Bilal, M., Alaka, H. A. and Owolabi, H. A. (2017a) Optimising material procurement for construction waste minimization: An exploration of success factors, Sustainable Materials and Technologies, 11, pp. 38-46. DOI:10.1016/j.susmat.2017.01.001.

Ajayi, S. O., Oyedele, L. O., Bilal, M., Akinade, O. O., Alaka, H. A. and Owolabi, H. A. (2017b) Critical management practices influencing on-site waste minimization in 
construction projects, Waste Management, 59, pp. 330-339. DOI:10.1016/j.wasman.2016.10.040.

Arif, S. and Abaza, H. (2012) Towards Greening the Solid Waste Sector in the Middle East and North Africa Region.

Azis, A. A. A., Memon, A. H., Rahman, I. A., Nagapan, S. and Latif, Q. B. A. I. (2012) Challenges faced by construction industry in accomplishing sustainablity goals, in: 2012 IEEE Symposium on Business, Engineering and Industrial Applications Challenges ISBEIA 2012. Bandung, Indonesia: IEEE Xplore, pp. 630-634.

Azmy, A. M. and El Gohary, R. (2017) Environmental and Sustainable Guidelines for Integrated Municipal Solid Waste Management in Egypt, in: International Conference on Advanced Technology in Waste Water and Waste Management for Extractive Industries. Nusa Dua, Bali, Indonesia,.

Caldas, C. H., Asce, M., Menches, C. L., Reyes, P. M., Navarro, L. and Vargas, D. M. (2014) Materials Management Practices in the Construction Industry, pp. 1-8. DOI:10.1061/(ASCE)SC.1943-5576.0000238.

Daoud, A. O., Othman, A. A. E., Robinson, H. and Bayyati, A. (2018a) Towards a Green Materials Procurement: Investigating the Egyptian Green Pyramid Rating System, in: 
Adel, M., El Maghraby, R., and Fathi, S. (eds.) Green Hiritage Conference: ChanageChange-Challenge. ElSherouk City, Cairo, Egypt: Elain Publishing House, pp. 575-591.

Daoud, A. O., Othman, A. A., Robinson, H. and Bayyati, A. (2018b) Exploring The Relationship Between Materials Procurement and Waste Minimization in The Construction Industry: The Case of Egypt, in: The 4th NZAAR International Event Series on Natural and Built Environment, Cities, Sustainability and Advanced Engineering. Kuala Lumpur, Malaysia: New Zealand Academy of Applied Research Ltd, pp. 76-85.

Dot Msr (2017) Removing 300 Tonnes of Construction Waste from Mansoura Streets. Available from: http://www.dotmsr.com/details/850191/3ور-رفع-طن-مخلفات_بناء-من شوارع-المنصورة [Accessed 9 December 2017].

Egyptian Ministry of Environment (EMoE) (2017) Report on the Evironment Status - Egypt 2016. Cairo.

El-Gamal, M. (2012) Municipal Solid Waste Management in Egypt - Focus on Cairo. $\begin{array}{lll}\text { Hamburg. } & \text { Available }\end{array}$ https://www.academia.edu/4805143/MUNICIPAL_SOLID_WASTE_MANAGEMEN T_IN_EGYPT___Focus_on_Cairo

El-Sherbiny, R., Gaber, A. and Riad, M. (2011) 2011 Report of the Arab Forum for 
Environment and Development. Beirut. Available from: http://www.afedonline.org/Report2011/PDF/En/chapter 7 Waste.pdf

Elgizawy, S. M., El-Haggar, S. M. and Nassar, K. (2016) Approaching Sustainability of Construction and Demolition Waste Using Zero Waste Concept, Low Carbon Economy, 7, pp. 1-11. DOI:10.4236/lce.2016.71001.

Elsaid, S. and Aghezzaf, E.-H. (2015) A Framework for Sustainable Waste Management: Challenges and Opportunities, Management Research Review, 24 (5), pp. 41-49. DOI:10.1108/EL-01-2014-0022.

Fadiya, O. O., Georgakis, P. and Chinyio, E. (2014) Quantitative Analysis of the Sources of Construction Waste, Journal of Construction Engineering, 2014, pp. 9.

Foo, L. C., Abdul Rahman, I., Asmi, A., Nagapan, S. and Khalid, K. I. (2013) Classification and quantification of construction waste at housing project site, International Journal of Zero Waste Generation, 1 (1), pp. 1-4.

Formoso, C. T., Soibelman, L., De Cesare, C. and Isatto, E. L. (2002) Material Waste in Building Industry: Main Causes and Prevention, Journal of Construction Engineering and Management, 128 (4), pp. 316-325. DOI:10.1061/(ASCE)07339364(2002)128:4(316). 
Garas, G. L., Anis, A. R. and El Gammal, A. (2001) Materials Waste in the Egyptian Construction Industry, in: Chua, D. and Ballard, G. (eds.) 9th International Group for Lean Construction Conference. Buona Vista, Singapore: National University of Singapore, pp. 1-8.

Hany, O. and Dulaimi, M. (2014) Creating a sustainable future: Solutions for the construction waste in the Greater Cairo, in: Okeil, A. (ed.) The First International Conference of the CIB Middle East \& North Africa Research Network (CIB-MENA 2014). Abu Dhabi, United Arab Emirates, pp. 281-305.

Hoornweg, D. and Bhada-Tata, P. (2012) What a Waste: A Global Review of Solid Waste $\begin{array}{lll}\text { Management. } & \text { Washington, } & \text { D.C. }\end{array}$ https://siteresources.worldbank.org/INTURBANDEVELOPMENT/Resources/3363871334852610766/What_a_Waste2012_Final.pdf

Housing and Building National Research Center (HBRC) (2011) The Green Pyramid Rating System - First Version. Vol. 2011. Ad Doqi, Giza.

Housing and Building National Research Center (HBRC) (2017) The Green Pyramid Rating System - Second Version. Ad Doqi, Giza.

Hussin, J., Rahman, I. A. and Memon, A. H. (2013) The Way Forward in Sustainable 
Construction: Issues and Challenges, International Journal of Advances in Applied Sciences (IJAAS), 2 (1), pp. 31-42. DOI:dx.doi.org/10.11591/ijaas.v2i1.1321.

Ibrahim, M. I. M. and Mohamed, N. A. E. M. (2016) Towards Sustainable Management of Solid Waste in Egypt, Procedia Environmental Sciences, 34, pp. 336-347. DOI:10.1016/j.proenv.2016.04.030.

Invest-gate (2016) Egyptian Government's Mega Projects 2016. Cairo. Available from: http://invest-gate.me/wp-content/uploads/2016/10/Egyptian-Government's-MegaProjects-2016-.pdf

Ismaeel, W. S. E., Rashed, A. and Toulibah (2018) To Be or Not to Be: The National Green Pyramid Rating System, in: Adel, M., El Maghraby, R., and Fathi, S. (eds.) Green Heritage Conference. ElSherouk City, Cairo, Egypt: Elain Publishing House, pp. LLXII.

Japanese Ministry of Environment (JMoE) (2004) Waste Management. Available from: https://www.env.go.jp/earth/coop/coop/c_report/egypt_h16/english/pdf/021.pdf [Accessed 1 July 2018].

Koskela, L. (1992) Application of the New Production Philosophy to Construction. Espoo. Available from: https://cife.stanford.edu/sites/default/files/TR072.pdf 
Lu, W. and Yuan, H. (2011) A framework for understanding waste management studies in construction, Waste Management, $31 \quad$ (6), $\quad$ pp. 1252-1260. DOI:10.1016/j.wasman.2011.01.018.

Marhani, M. A., Jaapar, A., Azmi, N., Bari, A. and Zawawi, M. (2013) Sustainability through Lean Construction Approach: A literature review, Procedia - Social and Behavioral Sciences, 101, pp. 90-99. DOI:10.1016/j.sbspro.2013.07.182.

Memon, N. A., Akram, M., Khahro, S. H. and Nicolae, P. (2015) Reduction of Construction Waste At Site, in: 3rd International Conference on Energy and Environment: Innovation, Research \& Sustainability 2015 (ICEE’15). Nawabshah: Quaid-e-Awam University of Engineering, Science and Technology (QUEST),.

Nagapan, S., Rahman, I. A. and Asmi, A. (2012) Factors Contributing to Physical and Non-Physical Waste Generation in Construction Industry, International Journal of Advances in Applied Sciences (IJAAS), 1 (1), pp. 1-10. DOI:10.11591/ijaas.v1i1.476.

Nassour, A., Elnaas, A., Hemidat, S. and Nelles, M. (2016) Development of Waste Management in the Arab Region, in: Thomé-Kozmiensky, K. J. and Thiel, S. (eds.) Waste Management - Waste-to-Energy. Volume 6. Munich: Universal Medien GmbH, pp. 117128. 
National Solid Waste Management Programme (NSWMP) (2014) National Strategic Directives for Waste Management in Egypt. Cairo.

Othman, A. A. E., Ghaly, M. A. and Zainul Abidin, N. (2014) Lean principles: an innovative approach for achieving sustainability in the Egyptian construction industry, Organization, Technology and Management in Construction: An International Journal, 6 (1), pp. 917-932. DOI:10.5592/otmcj.2014.1.2.

Redling, A. (2018) Construction debris volume to surge in coming years. Available from: http://www.cdrecycler.com/article/global-volume-construction-demolition-waste/ [Accessed 22 July 2018].

Roche, D. and Hegarty, S. (2006) Best practice guidelines on the preparation of waste management plans for construction and demolition projects. Dublin. Available from: https://www.leanbusinessireland.ie/includes/documents/BPGConstructionand demolition.pdf

Sharkiatoday (2017) Solid Waste Committee Continues its Campaign of Landfills' لجنة_المخلفات_الصلبة_بالثرقية-/ل Anspection. Available from: http://www.sharkiatoday.com [Accessed 12 August 2018].

Slowey, K. (2018) Report: Global construction waste will almost double by 2025 . Available 
from: https://www.constructiondive.com/news/report-global-construction-waste-willalmost-double-by-2025/518874/ [Accessed 22 July 2018].

United Nations Environment Programme (UNEP) (2009) Arab Regional Strategy for Sustainable Consumption and Production (Final Draft). Nairobi. Available from: http://www.unep.fr/scp/marrakech/publications/pdf/Final Draft Arab Strategy on SCP 06-10-09.pdf

US Environmental Protection Agency (EPA) (1995) Construction and Demolition Waste Landfills. Washington, D.C.

Yılmaz, M. and Bakış, A. (2015) Sustainability in Construction Sector, Procedia - Social and Behavioral Sciences, 195, pp. 2253-2262. DOI:10.1016/j.sbspro.2015.06.312.

Zafar, S. (2016) Waste Management Challenges in Middle East. Available from: https://www.bioenergyconsult.com/waste-management-middle-east/ [Accessed 27 June 2018].

Zaki, T. and Khial, A. (2014) Country Report on the Solid Waste Management in Egypt. Cairo. Available from: http://www.sweep-net.org/sites/default/files/EGYPT RA ANG 14_1.pdf 
Zeb, E. A., Malik, E. S., Nauman, S., Hanif, E. H., Muhammad, E. and Amin, O. S. (2015) Factors Affecting Material Procurement, Supply and Management in Building Projects of Pakistan: A Contractor' s Perspective, in: Proceedings of 2015 International Conference on Innovations in Civil and Structural Engineering (ICICSE'15). Istanbul, pp. $170-175$.

Zyoud, S. H., Al-Jabi, S. W., Sweileh, W. M., Al-Khalil, S., Zyoud, S. H., Sawalha, A. F. and Awang, R. (2015) The Arab world's contribution to solid waste literature: A bibliometric analysis, Journal of Occupational Medicine and Toxicology, 10 (1), pp. 19. DOI:10.1186/s12995-015-0078-1. 